\title{
USING INFORMATION AND COMMUNICATION TECHNOLOGY (ICT) TO ENHANCE LANGUAGE TEACHING \& LEARNING: AN INTERVIEW WITH DR. A. GUMAWANG JATI
}

\author{
Flora Debora Floris \\ (debora@peter.petra.ac.id) \\ Associate Editor \\ TEFLIN Journal
}

In recent years, information and communication technology (ICT) has become embedded and affected the every aspect of our lives. Rapid development of ICT has changed our language teaching pedagogy at all levels. Teachers, curriculum developers, researchers have been constantly striving to find techniques to use some form of it to both assist and enhance language learning. What is more exciting is that studies have demonstrated positive effects that ICT brings towards students' learning motivation (Chenoweth, Ushida \& Murday, 2006; SteppGreany, 2002), students' personal needs and learning styles (Gimenez, 2000), students' language mastery (Stepp-Greany, 2002), effective teaching and learning process (Al-Jarf, 2004), etc. Although these studies have shown that ICT has the potential important role in supporting and enhancing language learning, the use of ICT should never be the goal in and of itself. The responsibility for language instruction should be in the hands of qualified teachers who have the knowledge and expertise to manage and to make the best use of it to accomplish learning objectives.

This interview highlights the issue of bringing ICT into the English language classrooms. Dr. A. Gumawang Jati, a senior lecturer at Faculty of Arts and Design, Bandung Institute of Technology (ITB) who specializes in the area of Technology and Education, was interviewed to share his experiences and in- 
sights on how ICT could be effectively used to support the language development process.

1. Pak Jati, could you briefly describe your academic and professional background and what sparked your interest in the issues of ICT and language teaching/learning?

I finished my S1 degree from English Department IKIP Sanata Dharma in 1987. Then in 1988, I got a scholarship to continue my study at the University of Warwick. At that time I saw the rapid development of computer as a tool for almost anything, so I decided to work on Computer Assisted Language Learning (CALL) as my final project. Upon the completion of my study, I went back to Indonesia and started teaching English to pre-departure course at ITB. I learned a lot from the work designing a course, selecting teaching and learning materials and deciding the appropriate methods especially for adult learners. Then when I was the head of ITB Language Center, I started converting some self-study materials in the Self Access Centre into digital in a Local Area Network (LAN) and slowly putting them into the Language Centre website. In December 2002, I started learning Moodle 1.0 (now Moodle 2.6). I was amazed by its platform which resembles classroom. That was one of the enlightening moments in my life because I started to realize that ICT would be very beneficial for my teaching.

2. What is ICT and how important is it in the curriculum of language teaching and learning?

ICT refers to technologies that provide access to information through telecommunications. It is similar to Information Technology (IT), but focuses primarily on communication technologies. This includes the Internet, wireless networks, cell phones, and other communication mediums. ICT has become so essential in language learning. Its utilization in education has contributed to the improvement of language learning. In my opinion, ICT should be integrated in the curriculum to facilitate students and teachers in language teaching and learning process. 
3. What are the advantages and the disadvantages of the implementation of ICT in the process of language teaching and learning?

There are some advantages. First, both teachers and students of English can have quick and affordable access to the most up-to-date sources and information. Many focused exercises can be found on the net for free and software can be bought via Internet or in any store and some are free. Students can practice speaking in English with Siri in their iPad or iPhone or Assistant in their android devices. With the wide range of teaching and learning materials available for free in the Internet, teacher can select the ones that fit better to the students' needs according to their age, level, and abilities. There are also many discussion groups for professional development, interactive reading books for students, sound recordings for both teachers and students. I believe that ICT promotes student achievement because this tool allows them to progress at their pace and needs. With good access to sources of information, learners are also able to enhance their learning and creativity. Furthermore, the Internet also provides an easy and fast access to the current and authentic materials in the language being studied, which is motivating for language learners. Such authentic materials include, for instance, online newspapers, webcasts, podcasts, newsrooms, video clips or even video sharing websites such as YouTube. Another motivating language learning opportunity using ICT is provided by chat rooms and virtual environments such as Second Life which enable learners to practice the written and spoken language, without the fear of making mistakes.

There are some potential disadvantages of using ICT for language teaching. It is expensive for the first investment (computers, Internet connection, servers, employment of ICT personels, etc). It is also expensive in running ICT training for teachers (and administrative staff). Thus, teachers often have minimum exposure and experience in the use of ICT in English Language Teaching (ELT). Due to these potential problems, some institutions do not have the will to integrate ICT into their school system.

4. Would you please give us one or two examples on how to integrate ICT in language classrooms? 
A good example is to apply offline activities for Cartoon Story Maker (CSM). With CSM it is possible to make 2D screen-based cartoon stories to illustrate conversations and dialogues. Stories can include an unlimited number of frames and are viewed frame by frame. Each frame can include images, text bubbles, and voice recordings. Stories are then saved as HTML page (webpage) or printed. Completed stories can also be loaded back into the CSM and edited.

With this application, students can:

- create dialogues with their own text or voice recordings to demonstrate proficiency,

- create using digital photos of themselves acting out a situation and add either text or voice recordings to the photos, and

- $\quad$ search the web for culturally authentic images and import them into the $C S M$ as backgrounds to a story.

By using CSM, teachers can:

- provide a script or storyboard which students use to create a story,

- create partially completed stories which students can then open and complete,

- $\quad$ provide text only and students must add their own matching voice recordings, and

- $\quad$ provide questions to which students generate appropriate answers in the story.

5. How have your students responded to the use of ICT in language learning?

I first introduced blogging to my Technical Writing students in 2005. The students loved it for some reasons, e.g. free website, purposeful readers, etc. Their complaints were mostly related to the slow Internet access (see http://elt-gumawang.blogspot.com/2005/12/students-comment-technicalwrt.html for further description). So far I have integrated ICT in all classes that I teach. Students' response to ICT is always positive.

6. How have teachers and school administrators responded?

The biggest challenge in promoting the use of ICT is dealing with the institution. Some school leaders want to integrate ICT into teaching and 
learning merely for the sake of keeping up with technological and educational advancement. Some institutions do not have the will to integrate ICT into their school system at all. Some school leaders do not understand and believe in the benefits of ICT for their learners. Some school administrators or teachers who are new to the integration of ICT in the ELT curriculum are usually "trapped" into the sophisticated software and they just simply convert the teaching and learning materials into digital without considering the learning process. Designing digital materials is actually a very complex process. The complete procedures can be read at http://issuu.com/gumawang/docs/online_mat_dev.

7. What arguments do you think would be the most convincing in persuading reluctant school administrators or teachers about the benefits of ICT in language classrooms?

In the near future (it actually has started), everything that can be put into digital will be digitalized. With smart-phone generation, almost everything from computer will be put into the smart phone including learning languages. You can see it now at Play Store. Many scholars even have stated that it is now the time to move from CALL and to focus more on MALU (Mobile Assisted Language Use). I think in the future, our students will learn theories and read articles at home. The classroom would be a place for discussion and practice. This is what Flip Classroom is about. I understand this might be a problem for Indonesia since most of the English teachers are not ICT literate.

8. How would you help teachers to overcome their difficulties or reluctance using ICT in their language classrooms?

The only way I see now is by giving trainings. I always start with "eye opener" of what the education world will look like in the next decade. Then I introduce them to practical free software for language learning such as Hotpotatoes, Cartoon Story Maker, etc. I relate those applications into classroom activities and language learning theory. 
9. How about Teacher Education or Teacher Training programs? How can teacher preparation program help our student-teachers to acknowledge and respond to the role of ICT in language classrooms?

I think the teacher education program should have a CALL subject, which cover at least:

- The history of CALL

- How we learn a language

- Teaching and learning using CALL (including how to evaluate available commonly used software for education)

- Digital Learning and Teaching Materials (Principles of Digital Material Development, Evaluating some digital available materials, Creating digital materials for teaching and learning)

- Bloom's Digital Taxonomy

- 21 st Century Skills

- 3D tools

- Animation and comic strips

- Audio editing

- Online collaboration

- Online storage and sharing

- Social networking

- Learning management platform

10. If you are chosen as the coordinator for the implementation of ICT in a school with limited facilities and located in a remote area, what will be your first plan of action upon starting work?

First I will install the access to the Internet, which is possible in even remote areas with mobile network. Then I will train teachers on how to use email and Facebook for educational purposes. Next I will introduce them to some free website resources and encourage them to adapt those free materials for classroom activities. I will also create simple school blog for teachers and students. The whole process might need at least 3 years. 
11. Could you suggest some research areas or topics related to ICT in language classrooms that ELT scholars could explore?

There are many issues that still need further observations. Some of the plausible topics or areas are:

- Impact of ICTs on learning and achievement Monitoring and evaluation issues

- Equity issues: gender, special needs and marginalized groups

- Current implementations of ICTs in education: teaching, learning, content, curriculum, and tools

- ICT in Education Policy issues

12. Is there any final thought or suggestions about the use of ICT in language classrooms that you would like to leave us with?

I believe implementing ICT in the school will also improve the quality of teaching and learning when the schools do it right. It is very important that education systems develop e-content materials and do not merely digitalize the printed materials and conventional classroom interactions. If there is no e-content developed it is like building roads without cars on the road. ICT is not about purchasing computers for schools but upgrading skills and knowledge of teachers and administrators.

13. Thank you very much for sharing your expertise and experiences, Pak Jati. I am sure our readers will enjoy reading your insightful ideas. All the best for your future professional projects.

Thank you Bu Flora and TEFLIN Journal for inviting me to share my ideas and experiences. I hope our readers will get inspired and see ICT as an important tool in language education. If TEFLIN Journal readers would like to know more about this topic, please do not hesitate to contact me at gumawang.jati@gmail.com or visit my websites. 
146 TEFLIN Journal, Volume 25, Number 2, July 2014

\section{REFERENCES}

Al-Jarf, R. S. (2004), The effects of web-based learning on struggling EFL college writers. Foreign Language Annals, 37, 49-57. doi: 10.1111/j.19449720.2004.tb02172.x

Chenoweth, A.N., Ushida, E., \& Murday, K. (2006). Student learning in hybrid French and Spanish courses: An overview of language online. CALICO Journal, 26 (1), 115-146.

Gimenez, J. C. (2000). A self-access center for business English learners: Meeting individual learning needs. In E. Hanson-Smith (Ed.), Technologyenhanced learning environments (pp. 37-44). Alexandria, VA: TESOL.

Jati, G. (2005) Students' comment on Technical Wrt. Retrieved from http://eltgumawang.blogspot.com/2005/12/students-comment-technical-wrt.html

Jati, G. (2001) Online material development in designing a web-based course. Retrieved from http://issuu.com/gumawang/docs/online_mat_dev

Stepp-Greany, J. (2002). Student perceptions on language learning in a technological environment: Implications for the new millennium. Language Learning and Technology, 6 (1), 165-180. 